\title{
GOSPODARKA KOMUNALNA JAKO INSTRUMENT ZRÓWNOWAŻONEGO ROZWOJU W GMINIE NA PRZYKŁADZIE WŁADYSŁAWOWA
}

\section{Zrównoważony rozwój i jego charakterystyka}

Zasada zrównoważonego rozwoju wywodzi się z prawa międzynarodowego, z lat 60. i 70. minionego wieku, kiedy to ludzkość uświadomiła sobie zagrożenia spowodowane stanem środowiska i rozpoczęła poszukiwania nowego modelu gospodarowania. ${ }^{1}$ Pod pojęciem „zrównoważonego rozwoju” najczęściej rozumie się doktrynę polityczno-prawną mającą na celu zabezpieczenie dobrobytu i pokoju społecznego obecnym i przyszłym pokoleniom, przy usuwaniu dysproporcji podziału dóbr, z uwzględnieniem sytuacji środowiskowej i dynamiki demograficznej. Współcześnie, antropocentryczny zrównoważony rozwój utożsamiany jest z szeregiem działań. W jego zakresie mieści się sprawiedliwość międzypokoleniowa, określana także jako wewnątrzpokoleniowa czy międzygeneracyjna. ${ }^{2}$ Drugim jego nieodzownym elementem jest bezpieczeństwo: ekologiczne, ${ }^{3}$ żywnościowe, ${ }^{4}$ demograficzne, zdrowotne, socjalne, czy energetyczne. ${ }^{5} \mathrm{~W}$ końcu doktryna wspomina o rozwoju,

1 W literaturze polskiej, pierwsze pozycje wymieniające pojęcie zrównoważonego rozwoju, czy też ekorozwoju, pochodzą z lat 80. minionego wieku. K. Górka, B. Poskrobko, Ekonomika ochrony środowiska, Warszawa 1987, s. 25.

2 Z. Bukowski, Zrównoważony rozwój w systemie prawa, Toruń 2009, s. 30-32.

3 T. Bojar-Fijałkowski, Bezpieczeństwo ekologiczne, [w:] Bezpieczeństwo w administracji i biznesie, M. Grzybowski, J. Tomaszewski (red.), Gdynia 2007, s. 159-168. Większość obszarów, które mogą wpływać na poziom bezpieczeństwa ekologicznego w gminie leży jednakże w kompetencjach rządowej administracji powiatowej lub regionalnej. Tym samym decyzje względem tego, jak realizowane jest bezpieczeństwo ekologiczne w gminie, zapadają bez jej udziału. Gmina posiada, na przykład, kompetencje planistyczne, ale już nie kontrolne, bądź jedynie wykonawcze wobec decyzji podejmowanych poza nią. Stąd jej wpływ na poziom lokalnego bezpieczeństwa ekologicznego jest mocno ograniczony.

$4 \quad$ T. Bojar-Fijałkowski, Ustawa o bezpieczeństwie żywności i żywienia w służbie jakości i ekologii, [w:] Jakość, bezpieczeństwo, ekologia w sektorze rolno-spożywczym. Kierunki rozwoju, M. Wiśniewska, E. Malinowska (red.), Sopot 2008, s. 165-170.

5 J. Ciechanowicz-McLean, T. Bojar-Fijałkowski, Solidarność energetyczna Unii Europejskiej, [w:] Solidarność jako zasada działania Unii Europejskiej, C. Mik (red.), Toruń 2009, s. 257-268. 
ale gospodarczy stanowi jedynie jeden z obszarów jego realizacji przy społecznym, czy kulturowym. Tak rozumiana koncepcja stała się nadrzędnym, umocowanym prawnie, motywem długotrwałego rozwoju społeczeństw i gospodarek. ${ }^{6}$ Znaczenie zasady zrównoważonego rozwoju podkreślają także zapisy traktatowe Unii Europejskiej, choć prawo wspólnotowe samo w sobie nie zawiera definicji zrównoważonego rozwoju. ${ }^{7}$

Definicję formalną zrównoważonego rozwoju odnajdujemy w ustawie „Prawo ochrony środowiska", ${ }^{8}$ choć idea ta ${ }^{9}$ stanowi przedmiot zainteresowania szeregu nauk. ${ }^{10}$ Wedle polityki zrównoważonego rozwoju wzrost ekonomiczny musi być kompatybilny z systemem ekologicznym. ${ }^{11}$ Co ciekawe, aktualnie akcentuje się także wymiar socjalny, ${ }^{12}$ religijno-kulturowy, ${ }^{13}$ zdrowotny, ${ }^{14}$ czy turystyczny ${ }^{15}$ zrównoważonego rozwoju.

Podsumowując, zasadę zrównoważonego rozwoju określić można, za D. Pyć, jako próbę połączenia ochrony środowiska z rozwojem społecznym i ekonomicznym, w sposób sprawiedliwy dla obecnych i przyszłych pokoleń, za pomocą racjonalnego wykorzystywania bogactwa ziemi. ${ }^{16}$ Według Z. Bukowskiego, zrównoważony rozwój jako koncepcja odnosząca się do dalszej ewolucji życia ludzkiego na Ziemi ma istotne znaczeniu również na szczeblu lokalnym. Choć niewiele, bo 2,5\% polskich samorządów realizuje Agendę $21^{17}$ to w strategiach i planach rozwoju w większości przypadków cele zrównoważonego rozwoju są uwzględniane. Jak wszystkie zjawiska gospodarczo-społeczne, także powyższe są szczególnie dobrze widoczne w małej skali, stąd założenia zrównoważonego rozwoju odnaleźć można właśnie w aktach prawa miejscowego oraz praktyce, także praktyce gospodarki komunalnej.

Zobacz: D. Pyć, Prawo zrównoważonego rozwoju, Gdańsk 1996.

D. Pyć, Zasada zrównoważonego rozwoju, [w:] Europa sędziów, Z. Brodecki (red.), Warszawa 2007, s. 281.

Art. 3 punkt 50 ustawy z dnia 27 kwietnia 2001 roku „Prawo ochrony środowiska”, (Dz.U. z 2013 r., poz. 165 z późn. zm.). Choć są także przeciwnicy formalnego definiowania zrównoważonego rozwoju: B. Rakoczy, Wolność działalności gospodarczej a ochrona środowiska. Zasada zrównoważonego rozwoju, „Rzeczpospolita”, 21.05.2006, s. C4.

Zobacz: T. Bojar-Fijałkowski, W. Plopa, Zrównoważony rozwój - filozofia, która stała się prawem, [w:] Człowiek wobec III tysiąclecia, M. Plopa (red.), Elbląg 2009, s. 81-94.

T. Żylicz, Rola nauki w polityce trwałego rozwoju, „Ekonomia i Środowisko” 2002, nr 2, s. 57-70.

J. Nazarko, M. Dobrzyński, Zrównoważony rozwój - podejście holistyczne, [w:] Uwarunkowania ochrony środowiska. Aspekty krajowe, unijne, międzynarodowe, E.K. Czech (red.), Warszawa 2006, s. 15.

Zobacz: S. Torjman, The Social Dimension of Sustainable Development, Celadon Institute of Social Policy, Ottawa 2000.

Zobacz: L. Wynn, Religion, Culture and Sustainable Development, Princeton 2004.

Zobacz: H. Brehaut, Community Health Dimension of Sustainable Development in Developing Countries, Global Sustainability Services Inc. Canada 2003.

5 Zobacz: H. Ceballos-Lascuráin, Tourism, Ecotourism and Protected Areas: the State of Nature Based Tourism Around the World and Guidelines for its Development, Gland 1996; T. Bojar-Fijałkowski, Sport dla zdrowia, ekoturtystyka dla środowiska naturalnego. Aspekty zrównoważonego rozwoju, [w:] Sport i turystyka dla wszystkich w promocji zdrowego stylu życia, W.W. Gaworecki, Z. Mroczyński (red.), Gdańsk 2008, s. 79-84; N. Morwforth, I. Munt, Tourism and Sustainability: New Tourism in Third World, London 1998.

D. Pyć, Prawo zrównoważonego rozwoju, Gdańsk 1996, s. 41-42.

Z. Bukowski, Zrównoważony rozwój..., op. cit., s. 594. 


\section{Gmina i jej zadania}

Spośród trzech szczebli samorządu terytorialnego tylko gmina ma umocowanie konstytucyjne. ${ }^{18}$ Tam też wskazano, że jest ona podstawową jednostką samorządu terytorialnego. ${ }^{19} \mathrm{Z}$ faktu, iż Konstytucja czyni gminę podstawową jednostką samorządu terytorialnego wynika, zdaniem W. Skrzydło, konsekwencja prawna, że to gmina spełnia jego podstawowe zadania, a sprawy będące w gestii tego samorządu należą tym samym do kompetencji gminy i jej organów, zaś zadania innych jednostek muszą być wyraźnie przez prawo określone i im przyznane. ${ }^{20}$

Zadania z zakresu administracji publicznej między organy administracji rządowej i samorządowej rozdzielono po raz pierwszy zaraz po przywróceniu samorządu terytorialnego. ${ }^{21}$ Normy ustawowe aktualnie regulujące podział zadań gminy posługują się tu klasycznym podziałem na zadania własne i zlecone, przy czym, co podkreśla B. Dolnicki, w dość nieścisły i chaotyczny sposób posługując się zamiennie różnymi zwrotami. ${ }^{22}$ Ustawodawca wprowadził także klauzulę generalną domniemającą kompetencje właśnie gminy wobec innych organów samorządu terytorialnego, przy braku ich wyraźnego umocowania, co wyraźnie umocowuje szeroki zakres zadań własnych gminy.

Zadania zlecone najogólniej możemy określić jako zadania należące do administracji rządowej, ale wykonywane przez organy gminy na podstawie upoważnienia ustawowego, w zakresie organizacji wyborów i referendów lub porozumienia o powierzeniu takich zadań. ${ }^{23}$ Spośród własnych zadań gminy ${ }^{24}$ wszystkie bezpośrednio wiąże się z realizacją zrównoważonego rozwoju.

18 Art. 164, Konstytucji RP z dnia 2 kwietnia 1997 roku (Dz.U. Nr 78, poz. 483 z późn. zm.).

19 W ustawach o samorządzie terytorialnym zostały przewidziane dodatkowe różnice w ustrojach gmin wykonujących zadania o charakterze szczególnym, w tym w zakresie gmin uzdrowiskowych. Zob. T. Bojar-Fijałkowski, Prawo uzdrowiskowe w Polsce - stan i perspektywy, [w:] Turystyka zdrowotna i uzdrowiskowa, M. Boruszczak (red.), Gdańsk 2011, s. 219-229.

20 W. Skrzydło, Konstytucja Rzeczypospolitej Polskiej. Komentarz, Kraków 1999, s. 176.

21 Ustawa z dnia 17 maja 1990 roku o podziale zadań i kompetencji określonych w ustawach szczególnych pomiędzy organy gminy a organy administracji rządowej oraz o zmianie niektórych ustaw (Dz.U. Nr 34, poz. 198 z późn. $z m$.).

22 Są to zamiennie „kompetencje”, „zadania” i „sprawy”. Zob. B. Dolnicki, Samorząd terytorialny, Kraków 2006, s. 64 .

23 J. Zimmermann, Prawo administracyjne, Warszawa 2010, s. 190.

24 Art. 7 ustawy z dnia 8 marca 1990 roku o samorządzie gminnym (Dz.U. z 2013 r., poz. 153 z późn. zm.) wskazuje tu zadania związane z: techniczną infrastrukturą gminy, społeczną infrastrukturą, bezpieczeństwem publicznym, porządkiem przestrzennym oraz ekologicznym ładem, budową i utrzymaniem dróg, mostów, ulic, placów, jak również organizacji drogowego ruchu w gminie, ochroną środowiska i przyrody, ładem przestrzennym, gospodarką wodną, gospodarką nieruchomościami, usuwaniem i oczyszczaniem komunalnych ścieków, zaopatrzeniem w wodę i wodociągi, kanalizacją, wysypiskami i unieszkodliwianiem odpadów komunalnych, utrzymaniem urządzeń sanitarnych, utrzymaniem porządku i czystości, zaopatrzeniem w energię elektryczną oraz energię cieplną, zaopatrzeniem w gaz, ochroną zdrowia, edukacją publiczną, zielenią gminną, pomocą społeczną, lokalnym transportem zbiorowym, kulturą oraz ochroną zabytków i opieką nad nimi, gminnym budownictwem mieszkaniowym, kulturą fizyczną i turystyką, targowiskami oraz halami targowymi, utrzymaniem obiektów gminnych oraz urządzeń użyteczności publicznej, jak również administracyjnych obiektów, gminnymi cmentarzami, publicznym porządkiem, jak również bezpieczeństwem obywateli i ochroną przeciwpożarową i przeciwpowodziową, prorodzinną polityką, promocją gminy, współpracą z samorządowymi organizacjami, wspieraniem oraz upowszechniania samorządowej idei, w końcu współpracą z lokalnymi, jak również regionalnymi społecznościami innych krajów. 
Wykonywane przez gminy zadania, bardzo ogólnie, można też podzielić na trzy zasadnicze grupy: $:^{25}$

- w dziedzinie socjalno-kulturalnej, które wiążą się z opieką zdrowotną, społeczną, kulturą i sztuką oraz szkolnictwem szczebla podstawowego i gimnazjalnego, kulturą fizyczną i turystyką; ${ }^{26}$

- w dziedzinie administracji publicznej, które wiążą się m.in. z opodatkowaniem mieszkańców, ewidencją ludności, planowaniem przestrzennym, utrzymaniem ładu i porządku publicznego;

- w dziedzinie gospodarki komunalnej, które wiążą się z zaopatrywaniem w wodę, jak również transportem lokalnym, utrzymaniem zieleni, cmentarzami komunalnymi, drogami gminnymi czy też oczyszczaniem ścieków.

\section{Gospodarka komunalna i formy jej realizacji}

Ustawa $^{27}$ mówi, iż gospodarka komunalna jednostek samorządu terytorialnego, w tym gminy co jest przedmiotem rozważań niniejszej pracy, polega na wykonywaniu przez te jednostki zadań własnych, w celu zaspokojenia zbiorowych potrzeb wspólnoty samorządowej. Przy czym gospodarka komunalna obejmuje w szczególności zadania o charakterze użyteczności publicznej, których celem jest bieżące i nieprzerwane zaspokajanie zbiorowych potrzeb ludności w drodze świadczenia usług powszechnie dostępnych. ${ }^{28}$

Zadania te gmina wykonuje we własnym imieniu, jak również czyni to na własną odpowiedzialność w taki sposób, jaki został przewidziany w ustawie, czyli także w formie zakładu budżetowego lub spółki prawa handlowego. ${ }^{29}$ Ustawa wskazuje również na możliwość powierzania wykonywania zadań z zakresu gospodarki komunalnej osobom fizycznym, prawnym i jednostkom nieposiadającym osobowości prawnej przy uwzględnieniu m.in. prawa zamówień publicznych, ${ }^{30}$ regulacji koncesji na roboty budowlane ${ }^{31}$ czy partnerstwa publiczno-prawnego. ${ }^{32}$

M. Kosek-Wojnar, K. Surówka, Podstawy finansów samorządu terytorialnego, Warszawa 2007, s. 164.

Zob. T. Bojar-Fijałkowski, G. Cern, Rola organów jednostek samorządu terytorialnego w rozwoju turystyki w Polsce. Studium porównawczo-prawne, [w:] Uwarunkowania rozwoju turystyki w regionie, M. Boruszczak (red.), Gdańsk 2011, s. 271-289.

Art. 1 ustawy z dnia 20 grudnia 1996 roku o gospodarce komunalnej (Dz.U. Nr 45, poz. 236 z późn. zm.).

Więcej: J. Jagoda, D. Łobos-Kotowska, M. Stańko, Gospodarka mieniem komunalnym, Warszawa 2008, s. $60-74$.

Więcej: J.J. Zięty, Ustawa o gospodarce komunalne. Komentarz, Warszawa 2012, s. 35-41; T. Bojar-Fijałkowski, Realizacja zadań własnych gminy przez spółkę kapitałową na przykładzie Abruko Sp. z o.o. we Władysławowie, [w:] Zarządzanie w samorządzie terytorialnym, A. Kołomycew, B. Kotarba (red.), Rzeszów 2012, s. 428-443. Ustawa z dnia 29 stycznia 2004 roku Prawo zamówień publicznych (Dz.U. z 2012 r., poz. 1529, z późn. zm.). Ustawa z dnia 9 stycznia 2009 roku o koncesji na roboty budowlane lub usługi (Dz.U. z 2012 r., poz. 1271, z późn. $\mathrm{zm}$.).

Ustawa z dnia 19 grudnia 2008 roku o partnerstwie publiczno-prywatnym (Dz.U. z 2009 r., poz. 1342 z późn. zm.). Zobacz: T. Bojar-Fijałkowski, M. Dziedzic, Zakres podmiotowy umowy o partnerstwie publiczno-prywatnym na gruncie ustawodawstwa polskiego, „Przestrzeń. Ekonomia. Społeczeństwo” 2012, nr 1/l, s. 95-104. 
Co warte uwagi, ustawodawca ${ }^{33}$ zezwolił jednostkom samorządu terytorialnego na tworzenie spółek prawa handlowego, nawet poza sferą użyteczności publicznej, gdy służy to zaspokojeniu niezaspokojonych dotąd potrzeb wspólnoty samorządowej na rynku lokalnym. Warunkiem tegoż jest jednoczesne występowanie w gminie bezrobocia, które w znacznym stopniu wpływa ujemnie na poziom życia wspólnoty samorządowej, w sytuacji kiedy wcześniejsze zastosowanie innych działań i realizacja innych prawnych obowiązków gminy nie doprowadziły do aktywizacji gospodarczej, a w szczególności do znacznego ożywienia rynku lokalnego lub trwałego ograniczenia bezrobocia. ${ }^{34}$ Zapis ten w swoim założeniu całkowicie wypełnia cele zrównoważonego rozwoju społecznego i gospodarczego dając gminie prawo do wspomagania lokalnego rynku pracy, w tym kształtowania poziomu zatrudnienia oraz ingerowania i kształtowania lokalnej gospodarki w zakresie oferowanych towarów i usług, ich cen, czy jakości.

Choć prawo zamówień publicznych przewiduje formę przetargu jako zasadę lex generalis, to inne przepisy i orzeczenia zdają się temu przeczyć stając się poniekąd lex specialis w tym zakresie. I tak doszukać można się sądu, iż realizacja zadań komunalnych gminy przez jej spółkę jest realizacją w zakresie własnym, co tym samym nie wymaga ani formy wyboru najlepszej oferty, ani nawet umowy.

Na gruncie orzecznictwa Trybunału Sprawiedliwości Wspólnot Europejskich ${ }^{35}$ ukształtowało się pojęcie tak zwanych zamówień in house. W odniesieniu do udzielania zamówień publicznych odrębnym podmiotom prawa, w tym spółkom z ograniczoną odpowiedzialnością, należy wskazać, iż powszechnie przyjmuje się szeroką interpretację zamówień in house. Zakres powyższego pojęcia obejmuje zarówno zamówienia udzielane jednostkom organizacyjnie niewyodrębnionym, jak i samodzielnym podmiotom prawa, w tym komunalnym spółkom prawa handlowego.

Należy wskazać na przyjęte kryteria dopuszczenia udzielania zamówienia in house w drodze bezprzetargowej. ${ }^{36}$ Niezbędne jest tu sprawowanie przez instytucję zamawiającą kontroli nad wykonawcą zadania, przy czym zakres kontroli winien być analogiczny do sprawowanej wobec jednostek wewnętrznych. Ponadto działalność podmiotu zewnętrznego powinna być w co najmniej zasadniczym stopniu wykonywana na rzecz instytucji zamawiającej. W ślad za poglądami doktryny wskazać należy, iż jeżeli w akcie kreującym daną spółkę komunalną lub określającym zakres działalności tej spółki zostanie określony jej przedmiot działalności, to powierzenie przez gminę tej jednostce zadań publicznych do wykonywania nie podlega regulacji

33 Art. 10 ustawy z dnia 20 grudnia 1996 roku o gospodarce komunalnej (Dz.U. Nr 45, poz. 236 z późn. zm.).

34 Więcej: S. Czarnow, Cel i przedmiot przedsiębiorstwa gminy w świetle ustawy o gospodarce komunalnej, PUG 1997, nr 11.

35 W orzeczeniu ETS z dnia 8 maja 2003 roku w sprawie C-349/97 Hiszpania przeciwko Komisji Europejskiej oraz orzeczeniu ETS z dnia 7 grudnia 2000 roku w sprawie C-94/99 ARGE Gewässerschutz przeciwko Bundesministerium für Land - und Forstwirtschaft. 
prawa zamówień publicznych. ${ }^{37}$ Stąd możliwym jest powierzanie bezprzetargowe, a nawet bez umowy, zadań własnych gminy spółce, wszakże takiej, w której samorząd ten posiada całość udziałów lub akcji.

\section{Wykorzystanie gospodarki komunalnej do realizacji zrównoważonego rozwoju w gminie Władysławowo}

Gmina miejska Władysławowo, położona w powiecie puckim województwa pomorskiego, ${ }^{38}$ należy do najbardziej popularnych miejsc letniego wypoczynku w Polsce. Głównym powodem tegoż są atrakcyjne plaże ciągnące się wzdłuż wsi, dzielnic i miejscowości gminy od Karwii, przez Jastrzębią Górę, Rozewie, Cetniewo, Władysławowo, a na Chałupach skończywszy. Okres sezonu letniego cechuje znaczne zwiększenie stałej populacji gminy ${ }^{39}$ oraz potrzeb w zakresie usług, także publicznych. Specyficzną, z uwagi na dużą sezonowość, gospodarkę komunalną gmina realizuje m.in. przy pomocy trzech spółek prawa handlowego, w których posiada udziały: wodociągów, oczyszczalni ścieków oraz spółki wielobranżowej działającej pod firmą Abruko.

Abruko Sp. z o.o., ${ }^{40} \mathrm{w}$ 100\% własność gminy Władysławowo, obok komercyjnych usług oferowanych na wysoce konkurencyjnym rynku, świadczy szereg usługi zbieżnych z zadaniami własnymi gminy, w zakresie: budowy i konserwacji dróg, utrzymania terenów zielonych, letniego i zimowego oczyszczania miasta, zarządzania cmentarzem komunalnym i komunalnym zasobem mieszkaniowym oraz gminną infrastrukturą turystyczną w postaci kempingu. Ze współpracy z gminą, czyli właścicielem spółki, pochodzi przeszło połowa obrotów spółki.

Funkcjonowanie Abruko w formie spółki $\mathrm{z}$ ograniczoną odpowiedzialnością zbliżone jest, zarówno w praktyce gospodarczej, jak i zakresie zadań, do działalności zakładu budżetowego świadczącego swoje usługi odpłatnie, którego koszty działalności pokrywane są z przychodów własnych. Warto zauważyć, że po wejściu w życie nowego systemu samorządu terytorialnego wiele jednostek zdecydowało się na przekształcenie zakładów komunalnych w komunalne spółki prawa handlowego właśnie. ${ }^{41}$ Podmiot taki jak Abruko Sp. z o.o. analizować należy poza ramami prawa gospodarczego i finansowego, także w systemie szerokiego pojęcia administracji publicznej. Obok administracji bezpośredniej i pośredniej, J. Supernat wymienia prywatno-prawnie zorganizowaną administrację publiczną, którą tworzą podmioty zorganizowane $\mathrm{w}$ formach prawa prywatnego, a więc których forma or-

\footnotetext{
37 Powyższe stanowisko znajduje również uzasadnienie w wyroku Naczelnego Sądu Administracyjnego z dnia 11 sierpnia 2005 roku wydanego w sprawie o sygn. akt II GSK 105/2005. Więcej: www.wladyslawowo.pl

Z ok. piętnastu tysięcy stałych mieszkańców do przeszło ćwierć miliona przebywających w miesiącach letnich. Więcej: www.abruko.pl M. Szydło, Ustawa o gospodarce komunalnej. Komentarz, Warszawa 2008, s. 344.
} 
ganizacyjnoprawna oparta jest na przepisach prawa cywilnego i handlowego. ${ }^{42}$ Do grona tego należą z pewnością spółki kapitałowe. Podmioty te są w sensie organizacyjnym i funkcjonalnym częścią administracji publicznej, gdyż zostały powołane do wykonywania jej zadań. Niemniej jednak ich organizacja odbiega od organizacji pozostałych podmiotów administracji publicznej, jako że w ich przypadku w tym zakresie podstawową rolę odgrywa prawo prywatne. ${ }^{43}$ Sformułowanie to doskonale pasuje do spółki kapitałowej stanowiącej własność jednostki samorządu terytorialnego i wykonującej zadania własne tejże jednostki.

Z uwagi na władztwo gminy nad spółką oraz wykazaną powyżej możliwość powierzania jej realizacji zadań własnych poza procedurami zamówień publicznych w znacznie większym zakresie niż ma to miejsce w relacjach czysto rynkowych, gmina może uwzględniać w tych działaniach własne cele zrównoważonego rozwoju. Może mieć to miejsce zarówno w zakresie kształtowania poziomu zatrudnienia w spółce, wyboru profilu jej działania, czy bardziej szczegółowych elementów procesów świadczenia usług.

W ostatnich latach nie dało się nie zauważyć problemu, w sferze gospodarki, związanego z nienależytym wykonywaniem usług na rzecz inwestora publicznego. Jednym z powodów takiego stanu rzeczy była forma i tryb wyboru tegoż oferenta. Kierując się obawami o naruszenie dyscypliny finansów publicznych oraz podejrzeniami o działania korupcjogenne, nadmiernie często w procedurach zamówień publicznych stosowano wyłącznie kryterium ceny, wszakże dość łatwe do zastosowania. Efektem tego, często, realizowane inwestycje wymagały poprawek, przedłużały się w czasie, czy wymagały dodatkowych nakładów. Wszystko z powyższych skutkować może negatywnym efektem nie tylko ekonomicznym, ale i ekologicznym, co stawia taką realizację w sprzeczności ze wszystkimi założeniami zrównoważonego rozwoju. Ryzyko zaistnienia takiej sytuacji jest minimalizowane w sytuacji realizacji zadań własnych gminy, z zakresu gospodarki komunalnej, przez spółkę gminną.

Tezę tak stawianą potwierdza kazus tak zwanej „ustawy śmieciowej”, gdzie wyraźny zapis stanowił, iż spółka z udziałem gminy może odbierać odpady komunalne od właściciela nieruchomości, na zlecenie gminy, ale tylko w przypadku, gdy zostanie wyłoniona $\mathrm{w}$ drodze przetargu. ${ }^{44}$ Efektem czego pożądany efekt ekologiczny, w postaci segregacji odpadów komunalnych, zdaje się być osiągnięty jedynie w tych gminach, które z premedytacją pogwałciły zapis ustawy powierzając te zadania bezprzetargowo czy to własnym spółkom prawa handlowego, czy też zakładom budżetowym. W pozostałych przypadkach, nadzwyczaj często, skutek jest odwrotny niż

42 J. Supernat, www.supernat.pl [data dostępu: 5.05.2012].

43 Więcej: K. Pawłowicz, Nietypowe podmioty administrujące w sferze gospodarki, [w:] Prawo gospodarcze. Zagadnienia administracyjnoprawne, C. Banasiński, H. Gronkiewicz-Waltz, K. Pawłowicz, D. Szafrański, M. Wierzbowski, M. Wyrzykowski, Warszawa 2003.

44 Art. 6 lit. e ustawy z dnia 13 września 1996 roku o utrzymaniu czystości i porządku w gminach (Dz.U. 152, poz. 897 z późn. zm.). 
zakładany, gdyż wyłonione w procedurze zamówień publicznych, przy kryterium ceny, podmioty nie są $\mathrm{w}$ stanie realizować powierzonych zadań, umowy są rozwiązywane, a segregację odwleka się na czas późniejszy.

Stąd możliwość władczej kontroli nad wszystkimi etapami procesu inwestycyjnego przy realizacji zadań własnych gminy, szczególnie inwestycyjnych, od projektu, poprzez kosztorysowanie, wycenę, proces zakupu materiałów i usług, aż po wykonanie, monitorowanie, a na utrzymaniu i naprawach skończywszy, maksymalizuje szanse na skuteczne realizowanie założonych przez gminę celów zrównoważonego rozwoju.

\section{Podsumowanie}

Zrównoważony rozwój zdecydowanie wykracza poza obszar ochrony środowiska wyraźnie korelując z rozwojem społecznym i gospodarczym. Choć pochodzi on z polityki i prawa międzynarodowego, ma swoje wyraźne umocowanie lokalne, także pośród aktów prawa miejscowego, i to właśnie na szczeblu jednostek samorządu terytorialnego zachodzić może jego skuteczna realizacja.

Ustawodawca umożliwia gminie dość swobodne kształtowanie gospodarki komunalnej, wyraźnie wskazując na możliwość ingerencji w lokalny rynek także w celu skuteczniejszego osiągania celów społecznych, wpisujących się w założenia zrównoważonego rozwoju, czego gminy czasem nie dostrzegają czy nie wykorzystują hołdując ogólnym zasadom gospodarki rynkowej. Warto uwzględnić fakt, iż ustawa zasadnicza ustanawia na gruncie polskim społeczną odmianę gospodarki rynkowej, czego potwierdzeniem są, między innymi, przepisy o gospodarce komunalnej właśnie.

Prowadzenie gospodarki komunalnej poprzez spółkę komunalną stwarza gminie niebywałą możliwość bezpośredniej kontroli nad realizacją tych zadań. Możliwość indywidualnego kształtowania procesów gospodarczych daje jednostce samorządu terytorialnego sposobność na ominięcie złych i czasem niebezpiecznych reguł prawa zamówień publicznych. To dać może szansę na maksymalizację efektu ekonomicznego i ekologicznego przy realizacji celów zrównoważonego rozwoju, choć wymagać musi samokontroli i rozsądku, aby nie stało się narzędziem do nadużyć i patologii przewyższających omijane niebezpieczeństwa czy osiągane korzyści.

\section{BIBLIOGRAFIA}

Bojar-Fijałkowski T., Bezpieczeństwo ekologiczne, [w:] Bezpieczeństwo w administracji i biznesie, M. Grzybowski, J. Tomaszewski (red.), Gdynia 2007.

Bojar-Fijałkowski T., Prawo uzdrowiskowe w Polsce - stan i perspektywy, [w:] Turystyka zdrowotna i uzdrowiskowa, M. Boruszczak (red.), Gdańsk 2011. 
Bojar-Fijałkowski T., Realizacja zadań własnych gminy przez spółkę kapitałową na przykładzie Abruko Sp. z o.o. we Władysławowie, [w:] Zarządzanie w samorządzie terytorialnym, A. Kołomycew, B. Kotarba (red.), Rzeszów 2012.

Bojar-Fijałkowski T., Sport dla zdrowia, ekoturtystyka dla środowiska naturalnego. Aspekty zrównoważonego rozwoju, [w:] Sport i turystyka dla wszystkich w promocji zdrowego stylu życia, W.W. Gaworecki, Z. Mroczyński (red.), Gdańsk 2008.

Bojar-Fijałkowski T., Ustawa o bezpieczeństwie żywności i żywienia w służbie jakości i ekologii, [w:] Jakość, bezpieczeństwo, ekologia w sektorze rolno-spożywczym. Kierunki rozwoju, M. Wiśniewska, E. Malinowska (red.), Sopot 2008.

Bojar-Fijałkowski T., Cern G., Rola organów jednostek samorządu terytorialnego w rozwoju turystyki w Polsce. Studium porównawczo-prawne, [w:] Uwarunkowania rozwoju turystyki w regionie, M. Boruszczak (red.), Gdańsk 2011.

Bojar-Fijałkowski T., Dziedzic M., Zakres podmiotowy umowy o partnerstwie publiczno-prywatnym na gruncie ustawodawstwa polskiego, „Przestrzeń. Ekonomia. Społeczeństwo” 2012, nr 1/I, s. 95-104.

Bojar-Fijałkowski T., Plopa W., Zrównoważony rozwój - filozofia, która stała się prawem, [w:] Człowiek wobec III tysiąclecia, M. Plopa (red.), Elbląg 2009.

Brehaut H., Community Health Dimension of Sustainable Development in Developing Countries, Global Sustainability Services Inc., Canada 2003.

Bukowski Z., Zrównoważony rozwój w systemie prawa, Torun 2009.

Ceballos-Lascuráin H., Tourism, Ecotourism and Protected Areas: the State of Nature Based Tourism Around the World and Guidelines for its Development, Gland 1996.

Ciechanowicz-McLean J., Bojar-Fijałkowski T., Solidarność energetyczna Unii Europejskiej, [w:] Solidarność jako zasada działania Unii Europejskiej, C. Mik (red.), Toruń 2009.

Czarnow S., Cel i przedmiot przedsiębiorstwa gminy w świetle ustawy o gospodarce komunalnej, PUG 1997, nr 11.

Dolnicki B., Samorząd terytorialny, Kraków 2006.

Górka K., Poskrobko B., Ekonomika ochrony środowiska, Warszawa 1987.

Jagoda J., Łobos-Kotowska D., Stańko M., Gospodarka mieniem komunalnym, Warszawa 2008.

Kosek-Wojnar M., Surówka K., Podstawy finansów samorządu terytorialnego, Warszawa 2007.

Morwforth N., Munt I., Tourism and Sustainability: New Tourism in Third World, London 1998.

Nazarko J., Dobrzyński M., Zrównoważony rozwój - podejście holistyczne, [w:] Uwarunkowania ochrony środowiska. Aspekty krajowe, unijne, międzynarodowe, E.K. Czech (red.), Warszawa 2006.

Pawłowicz K., Nietypowe podmioty administrujące w sferze gospodarki, [w:] Prawo gospodarcze. Zagadnienia administracyjnoprawne, C. Banasiński, H. Gronkiewicz-Waltz, K. Pawłowicz, D. Szafrański, M. Wierzbowski, M. Wyrzykowski, Warszawa 2003.

Pyć D., Prawo zrównoważonego rozwoju, Gdańsk 1996.

Pyć D., Zasada zrównoważonego rozwoju, [w:] Europa sędziów, Z. Brodecki (red.), Warszawa 2007. 
Rakoczy B., Wolność działalności gospodarczej a ochrona środowiska. Zasada zrównoważonego rozwoju, ,Rzeczpospolita”, 21.05.2006.

Skrzydło W., Konstytucja Rzeczypospolitej Polskiej. Komentarz, Kraków 1999.

Szydło M., Ustawa o gospodarce komunalnej. Komentarz, Warszawa 2008.

Torjman S., The Social Dimension of Sustainable Development, Celadon Institute of Social Policy, Ottawa 2000.

Wynn L., Religion, Culture and Sustainable Development, Princeton 2004.

Zięty J.J., Ustawa o gospodarce komunalne. Komentarz, Warszawa 2012.

Zimmermann J., Prawo administracyjne, Warszawa 2010.

Żylicz T., Rola nauki w polityce trwałego rozwoju, „Ekonomia i Środowisko” 2002, nr 2. 
Gospodarka komunalna jako instrument zrównoważonego rozwoju w gminie...

\section{COMMUNAL ECONOMY AS AN INSTRUMENT OF SUSTAINABLE DEVELOPMENT IN THE COMMUNITY ON THE EXAMPLE OF WŁADYSŁAWOWO}

The aim of the article is to indicate that communal economy can be an instrument of sustainable development. Therefore, at the outset sustainable development is described along with its role in community performance. It is correlated with further divagations on communal economy and implementation of community duties neglecting procurement law. The article concludes by casus of the city community of Władysławowo and some general remarks on the issue. The text is based on Polish and international legal literature. Legal acts quoted are valid as at August $20^{\text {th }}$ of 2013.

Keywords: sustainable development, communal economy, community 